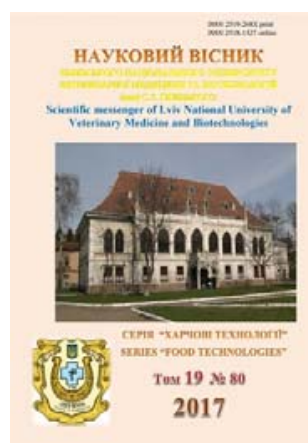

Науковий вісник Львівського національного університету ветеринарної медицини та біотехнологій імені С.З. Гжицького

Scientific Messenger of Lviv National University of Veterinary Medicine and Biotechnologies

doi:10.15421/nvlvet8021

ISSN 2519-268X print

ISSN 2518-1327 online

$\underline{\text { http://nvlvet.com.ua/ }}$

УДК 577.1: 636.4.084

\title{
Вплив різних сполук заліза на хімічний та мікроелементний склад печінки свиней
}

\author{
М.В. Фоміна, Б.М. Калин, Г.М. Коваль \\ fominam@bigmir.net \\ Львівський національний університет ветеринарної медицини та біотехнологій імені С.3. Гжицького, \\ вул. Пекарська, 50, Львів, 79010, Україна
}

Поряд з м'ясом, печінці як продукту харчування відводиться важливе місце у забезпеченні людини важливими харчовими компонентами: білковими, ліпідними, вітамінами та мінеральними речовинами. Так, в ній синтезуються та резервуються не тільки білки власних тканин, а й білки крові. У ній міститься великий запас глікогену. В печінці синтезуються та тимчасово нагромаджуються ліпіди, які в нормальних умовах в ній окиснюються. Цей орган першим реагує на фактори годівлі, в тому числі на негативні.

Макроскопічно печінка свиней всіх груп була в нормальному об'ємі, мала загострені краї, капсула тонка, погано знімається, колір з поверхні та на розрізі - темно-вишневий; консистенція - трохи щільнувата, поверхня розрізу - волога, з окремих великих судин при натискуванні на край розрізу виділялася незначна кількість крові. Маса печінки свиней складала 1931, 1976 та 1989 г порівняно з 1902 г в контрольній групі, тобто була вищою відповідно на 1,5\%, 3,9\% і 4,6\% порівняно 3 контрольною групою.

Хімічний склад продуктів тваринництва можна вважати дзеркальним відображенням хімічного складу навколишнього середовища в иілому і кормів зокрема. Ефект, щзо спостерігається за нестачі заліза, обумовлений не лише концентрацією його в крові, а й у м'яких тканинах та печінці. Тому важливим етапом в нашій роботі є визначення вмісту мінеральних речовин в печіниі свиней при згодовуванні різних сполук і доз заліза. При дослідженні вмісту кальиію та фосфору у печіниі свиней встановили, що у дослідних тварин вищезгадані показники були вищими відносно контролю.

Не менш важливе значення в живому організмі відіграють мікроелементи, а саме залізо, мідь, марганець, та інші, які беруть участь у переважній більшості обмінних прочесів в клітинах і тканинах. Нами відмічено зростання даних мікроелементів у печінці тварин контрольної та дослідних груп впродовж всього досліду.

Аналізуючи вміст заліза, слід відзначити, щьо найвищий його рівень був у печінці тварин III групи, а найменшим - контрольної групи. Застосування мікроелементів та їх хелатів позитивно впливало і на вміст иинку та міді в печіниі свиней, їх рівень збільшився на 5,3-12,5\% (Zn) та 6,9-18,1\% (Mn) у дослідних групах відносно контрольної. Рівень свинщю у печінці не перевищував ГДК.

Ключові слова: свині, відгодівля, хелати, залізо, печінка, екологічний моніторинг, хімічний та мікроелементний склад, важкі метали.

\section{Влияние различных соединений железа на химический и микроэлементный состав печени свиней}

\author{
М.В. Фомина, Б.Н. Калин, Г.М. Коваль \\ fominam@bigmir.net
}

Львовский национальный университет ветеринарной медицины и биотехнологий имени С.3. Гжицкого, ул. Пекарская, 50, г. Львов, 79010, Украина

Наряду с мясом, печени как продукту питания отводится важное место в обеспечении человека важными пищевьии

Fomina, M., Kalyn, B., Koval, H. (2017). Influence of different connections of iron on chemical and microelement composition of liver of pigs. Scientific Messenger LNUVMB, 19(80), 103-106. 
компонентами: белковыми, липидными, витаминами и минеральными вешествами. Так, в ней синтезируются и резервируются не только белки собственных тканей, но и белки крови. В ней содержится большой запас гликогена. В печени синтезируются и временно накапливаются липиды, которые в нормальных условиях в ней окисляются. Этот орган первым реагирует на факторы кормления, в том числе на отрицательные.

Макроскопически печень свиней всех групп была в нормальном объеме, имела заостренные края, капсула тонкая, плохо снимается, цвет с поверхности и на разрезе - темно-вишневый; консистенция - немного плотноватая, поверхность разреза - влажная, из отдельных крупных сосудов при нажатии на край разреза выделялась незначительное количество крови. Масса печени свиней составляла 1931, 1976 и 1989 г по сравнению с 1902 г в контрольной группе, то есть была выие соответственно на 1,5\%, 3,9\% и 4,6\% по сравнению с контрольной группой.

Химический состав продуктов животноводства можно считать зеркальным отражением химического состава окружаюшей среды в цуелом и кормов в частности. Эффект, который при недостатке железа, обусловлен не только концентрацией его в крови, но и в мягких тканях и печени. Поэтому важным этапом в нашей работе является определение содержания минеральных веществ в печени свиней при скармливании различных соединений и доз железа. При исследовании содержания кальция и фосфора в печени свиней установили, что у опытных животных вымеупомянутые показатели были выме относительно контроля.

Не менее важное значение в живом организме играют микроэлементы, а именно железо, медь, марганеи и другие, которые участвуют в больиинстве обменных процессов в клетках и тканях. Нами отмечен рост данных микроэлементов в печени животных контрольной и опытных групп в течение всего опыта.

Анализируя содержание железа, следует отметить, что самый высокий его уровень был в печени животных ІІІ групnы, а наименьшим - контрольной группы. Применение микроэлементов и их хелатов положительно влияло и на содержание цинка и меди в печени свиней, их уровень увеличился на 5,3-12,5\% (Zn) и 6,9-18,1\% (Mn) в опьтньх группах относительно контрольной. Уровень свинца в печени не превышал ПДК.

Ключевые слова: свиньи, откорм, хелаты, железо, печень, экологический мониторинг, химический и микроэлементный состав, тяжелье металль.

\title{
Influence of different connections of iron on chemical and microelement composition of liver of pigs
}

\author{
M. Fomina, B. Kalyn, H. Koval \\ fominam@bigmir.net \\ Stepan Gzhytskyi National University of Veterinary Medicine and Biotechnologies Lviv, \\ Pekarska Str., 50, Lviv, 79010, Ukraine
}

\begin{abstract}
Along with meat, the liver as a food product is given an important place in providing the person with important food components: protein, lipid, vitamins and minerals. So, it synthesizes and reserves not only the proteins of own tissues, but also proteins of blood. It contains a large stock of glycogen. In the liver, lipids are synthesized and temporarily accumulated, which, under normal conditions, are oxidized in it. This body is the first to respond to feeding factors, including negative ones.

Macroscopically, the liver of the pigs of all groups was in normal volume, the small sharp pointed edges, the capsule is thin, poorly removed, the color from the surface and on the cut - dark cherry; the consistency - a little dense, the surface of the cut moisture, from some large vessels at the pressure on the edge of the cut a small amount of blood was allocated. The weight of the liver of pigs was 1931, 1976 and 1989, compared to 1902 in the control group, that is, it was higher by 1.5\%, 3.9\% and 4.6\%, respectively, in comparison with the control group.

The chemical composition of livestock products can be considered a mirror image of the chemical composition of the environment as a whole and feed, in particular. The effect observed due to iron deficiency is due not only to its concentration in the blood, but also in the soft tissues and the liver. Therefore, an important step in our work is to determine the content of minerals in the liver of pigs when feeding various compounds and iron doses. In researching the content of calcium and phosphorus in the liver of pigs, it was found that in the experimental animals the above-mentioned parameters were higher in relation to control.

Microorganisms, namely iron, copper, manganese, and others, which participate in the vast majority of metabolic processes in cells and tissues, play an important role in the living organism. We noted the growth of trace elements in the liver of animals in control and experimental groups throughout the experiment.

Analyzing the content of iron, it should be noted that its highest level was in the liver of animals of the third group, and the smallest - the control group. The application of micronutrients and their chelates also positively influenced the content of zinc and copper in the liver of pigs, their level increased by 5.3-12.5\% ( $\mathrm{Zn})$ and $6.9-18.1 \%(\mathrm{Mn})$ in experimental groups relative to the control group. The level of lead in the liver did not exceed the MAC.
\end{abstract}

Key words: pigs, fattening, chelates, iron, liver, ecological monitoring, chemical and microelement composition, heavy metals.

\section{Вступ}

Безпечність харчових продуктів є важливим питанням, нерозривно пов'язаним зі здоров'ям суспільства у всіх країнах світу. За даними Всесвітньої організації здоров’я, захворювання, що асоціюються з харчовими продуктами, являють собою надзвичайно складну для вирішення проблему, не тільки у країнах, що розвиваються, а й у розвинутих країнах з огляду на суттєву шкоду для здоров'я людей та значні економічні збитки. Якість харчових продуктів регламентується нормативною документацією, а якість продовольчої сировини, з якої виготовляються харчові продукти, - ще й ветеринарними і фіто-санітарними вимогами. 
В сучасних умовах у зв'язку зі значним забрудненням всіх біосередовищ (грунту, води, повітря, рослин, кормів), ставиться завдання не тільки підвищення обсягів виробництва, а й якості продуктів харчування, що характеризуються оптимальною фізіологічною корисністю і відповідають нормальним потребам організму людини (Cook et al., 1992; Kalyn et al., 2013).

Поряд з м'ясом, печінці як продукту харчування відводиться важливе місце у забезпеченні людини важливими харчовими компонентами: білковими, ліпідними, вітамінами та мінеральними речовинами (Melnykova et al., 2010).

Як відомо, в процесах обміну речовин свиней важлива роль належить печінці. Так, в ній синтезуються та резервуються не тільки білки власних тканин, а й білки крові (Sikora and Zakhliebaieva, 2005). Печінка регулює в організмі обміни вуглеводів, ліпідів та інших речовин. У ній міститься великий запас глікогену. В печінці синтезуються та тимчасово нагромаджуються ліпіди, які в нормальних умовах у ній окиснюються. Цей орган першим реагує на фактори годівлі, в тому числі на негативні. Нетрадиційні кормові засоби, а також поєднання декількох нетоксичних речовин можуть негативно впливати на організм свиней при їх комбінуванні один $з$ одним, а також 3 iншими речовинами раціону, викликаючи зміни на тканинному, клітинному та субклітинному рівнях (Vlizlo et al., 2004).

Метою роботи було вивчення хімічного та мінерального складу печінки у свиней на відгодівлі при використанні хелатних сполук заліза.

\section{Матеріал і методи досліджень}

Дослідження проводили на відгодівельному молодняку свиней великої білої породи протягом 122 днів у навчально-науково-виробничому центрі (ННВЦ) «Комарнівський» Городоцького району Львівської області. Для проведення досліду було сформовано чотири групи тварин: одна контрольна і три дослідні, по 10 голів у кожній групі. Підбір тварин у групи проводили за методом груп-аналогів з урахуванням віку, маси тіла та інтенсивності росту за підготовчий період.

Тварини контрольної групи отримували основний раціон (ОР). Поросята I дослідної групи отримували ОР $з$ добавками сірчанокислого заліза у дозі 0,8 мг/кг маси тіла; II - OP з добавками метіонату заліза у дозі 0,4 мг/кг маси тіла; III - OP з добавками лізинату заліза у дозі 0,4 мг/кг маси тіла. У печінці, яку відібрали після забою свиней, визначали концентрацію мікроелементів (Fe, $\mathrm{Mn}, \mathrm{Zn}, \mathrm{Cu}, \mathrm{Co}, \mathrm{Ni}, \mathrm{Pb}, \mathrm{Cd}$ ) на атомно-абсорбційному спектрофотометрі AAS-30. Вміст сухої речовини, протеїну, жиру та золи досліджували за загальноприйнятими методиками (Kalyn and Sukhorska, 2014).

Для встановлення ступеня вірогідності отриманих результатів дослідження проводили біометрично за методикою I.А. Ойвіна. Для аналізу табличного матеріалу прийняті такі умовні позначення: * $-\mathrm{P}<0,05$; $* *-\mathrm{P}<0,02 ; * * *-\mathrm{P}<0,01 ; * * * *-\mathrm{P}<0,001$.

\section{Результати та їх обговорення}

Наявність у печінці різних метаболічних зв'язків, участь у компенсаторно-пристосувальних процесах диктують необхідність вивчення іï в різних реакціях напруги. Морфологічні дослідження свідчать про високу чутливість печінки до дії різних екзогенних чинників, зокрема екотоксикантів, серед яких важкі метали відносять до найнебезпечніших (Rozputnii, 1997; Kalyn and Sukhorska, 2014).

Макроскопічно печінка свиней всіх груп була в нормальному об'ємі, мала загострені краї, колір 3 поверхні та на розрізі - темно-вишневий; консистенцію - трохи щільнувату, поверхня розрізу - волога, 3 окремих великих судин при натискуванні на край розрізу виділялася незначна кількість крові.

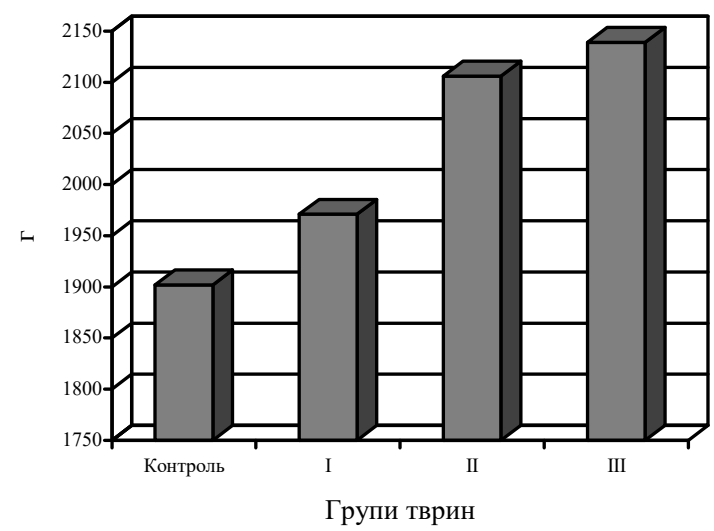

Рис. 1. Маса печінки дослідних свиней, г

Маса печінки свиней складала 1971, 2106 та 2139 г порівняно з 1902 г в контрольній групі, тобто була вищою відповідно на $3,6 \%(\mathrm{P}<0,05), 10,7 \%(\mathrm{P}<0,02)$ i $12,5 \%(\mathrm{P}<0,01)$ порівняно 3 контрольною групою (рис. 1).

Дефіцит чи надлишок життєвоважливих, а також накопичення токсичних хімічних елементів в організмі людини і тварин залежить від локальних біогеохімічних циклів цих елементів. Внаслідок дисбалансу біологічно активних хімічних елементів у довкіллі порушується їх вміст у рослинах, кормах, організмі тварин, що призводить до зниження продуктивності, працездатності та виникнення захворювань у тварин (Kravtsiv, 2000).

Хімічний склад продуктів тваринництва можна вважати дзеркальним відображенням хімічного складу навколишнього середовища в цілому і кормів, зокрема. Ефект, що спостерігається за нестачі заліза, обумовлений не лише концентрацією його в крові, а й у м'яких тканинах та печінці. Тому важливим етапом в нашій роботі $\epsilon$ визначення вмісту мінеральних речовин у печінці свиней при згодовуванні різних сполук $\mathrm{i}$ доз заліза (Mazvila et al., 2001).

При дослідженні вмісту кальцію та фосфору в печінці свиней встановили (табл. 1), що у дослідних тварин вищезгадані показники були вищими відносно контролю: на 2,2 та 2,4\% - I група, 7,6 та 3,3\% II група, 10,6 (P < 0,05) та 4,3\% - III група. 
Вміст кальцію та фосфору в печінці піддослідних свиней, мг/100 г, M \pm m, n =3

\begin{tabular}{|c|c|c|c|c|}
\hline \multirow{2}{*}{ Показник } & \multicolumn{4}{|c|}{ Групи тварин } \\
\cline { 2 - 5 } & Контрольна & I & II & III \\
\hline $\mathrm{Ca}$ & $5,37 \pm 0,14$ & $5,49 \pm 0,18$ & $5,78 \pm 0,13$ & $54 \pm 0,11^{*}$ \\
\hline $\mathrm{P}$ & $95,17 \pm 2,45$ & $97,44 \pm 2,49$ & $98,31 \pm 2,56$ & $99,26 \pm 2,38$ \\
\hline
\end{tabular}

Печінці належить головна детоксикуюча роль екзогенних токсичних речовин, які екскретуються разом iз жовчю. Тому вона часто підлягає хімічній агресії. За умов хронічної інтоксикації тварин важкими металами спостерігаються різні за ступенем вираженості дистрофічні зміни печінки із ознаками токсичного гепатиту (Kalyn and Sukhorska, 2014).

3 даних таблиці 2 видно, що після згодовування хелатних сполук заліза у печінці свиней концентрація мікроелементів в дослідних групах збільшилась порівняно з тваринами контрольної групи. Так, вміст залі- за у м'ясі тварин, порівняно з контролем, був вищим у I групі на $13,5 \%$, у II - на 19,2\%, у III - на $21,7 \%$ (P < $0,05)$; марганцю - на 6,$9 ; 12,5 ; 18,1 \%$; цинку - на 5,3; 10,$6 ; 12,5 \%(\mathrm{P}<0,05)$; міді - на 5,5; 19,9 (P < 0,05); 20,8\% (P < 0,02). Рівень нікелю та свинцю у печінці знизився у І-ІІІ дослідних групах тварин відповідно на 21,4-35,7 і 17,4-40,0 (P < 0,05)\%, що можна пояснити антагоністичними відносинами даних елементів 3 залізом. Рівень кадмію практично не змінився і не перевищував ГДК.

Мікроелементний склад печінки свиней, мг/кг, $\mathbf{M} \pm \mathbf{m}, \mathbf{n}=\mathbf{3}$

Табличя 2

\begin{tabular}{|c|c|c|c|c|}
\hline \multirow{2}{*}{ Показник } & \multicolumn{4}{|c|}{ Групи тварин } \\
\cline { 2 - 5 } & Контрольна & I & II & III \\
\hline $\mathrm{Fe}$ & $53,09 \pm 6,21$ & $60,28 \pm 6,45$ & $63,31 \pm 6,89$ & $64,65 \pm 6,27^{*}$ \\
\hline $\mathrm{Mn}$ & $0,72 \pm 0,12$ & $0,77 \pm 0,14$ & $0,81 \pm 0,17$ & $0,85 \pm 0,16$ \\
\hline $\mathrm{Zn}$ & $44,18 \pm 2,16$ & $46,52 \pm 2,30$ & $48,87 \pm 2,42$ & $49,74 \pm 2,11^{*}$ \\
\hline $\mathrm{Cu}$ & $2,16 \pm 0,09$ & $2,28 \pm 0,11$ & $2,59 \pm 0,08^{*}$ & $2,61 \pm 0,09^{*}$ \\
\hline $\mathrm{Co}$ & $0,030 \pm 0,01$ & $0,031 \pm 0,01$ & $0,029 \pm 0,02$ & $0,034 \pm 0,01$ \\
\hline $\mathrm{Ni}$ & $0,42 \pm 0,04$ & $0,31 \pm 0,01$ & $0,33 \pm 0,04$ & $0,27 \pm 0,03^{*}$ \\
\hline $\mathrm{Pb}$ & $0,46 \pm 0,03$ & $0,38 \pm 0,03$ & $0,36 \pm 0,04$ & $0,29 \pm 0,05^{*}$ \\
\hline $\mathrm{Cd}$ & $0,032 \pm 0,02$ & $0,029 \pm 0,01$ & $0,031 \pm 0,01$ & $0,029 \pm 0,01$ \\
\hline
\end{tabular}

\section{Висновки}

Використання хелатних сполук заліза у годівлі свиней сприяє підвищенню якості свинини та ії̈ біологічної цінності.

Встановлено покращення мінерального складу печінки порівняно з контролем у всіх дослідних групах, причому засвоєння мікроелементів відбувалося краще при застосуванні хелатних сполук заліза.

Доброякісність та екологічна чистота печінки підтверджена фізико-хімічними аналізами іiі складу i вмістом у ній важких металів.

\section{Бібліографічні посилання}

Vlizlo, V.V., Fedoruk, R.S., Makar, I.A., Ratych, I.B., Solohub, L.I., Ianovych, V.H. (2004). Dovidnyk: Fizioloho-biokhimichni metody doslidzhen, shcho zastosovuiutsia u biolohii, tvarynnytstvi ta veterynarnii medytsyni (in Ukrainian).

Kalyn, B.M., Sukhorska, O.P. (2014). Okremi aspekty ekolohizatsii silskoho hospodarstva u Lvivskii oblasti. Materialy mizhnar. nauk.-prakt. konf. «Ekolohiia i pryrodokorystuvannia $\mathrm{v}$ systemi optymizatsii vidnosyn pryrody i suspilstva» Ternopil: Krok, 122124 (in Ukrainian).

Kalyn, B.M., Fomina, M.V., Dashkovskyi, O.O. (2013). Yakist ta ekolohichna bezpeka produktiv tvarynnytstva, otrymanykh $\mathrm{v}$ umovakh lokalnoho tekhnohennoho zabrudnennia. Tezy dop. Mizhnar. nauk.-prakt. konf. «Upravlinnia yakistiu v osviti ta promyslovosti: dosvid, problemy ta perspektyvy». Lviv (in Ukrainian).

Kravtsiv, R.I. (2000). Problemy mikroelementnoho zhyvlennia tvaryn i ptytsi, yakosti vyroblenoi produktsii, profilaktyky mikroelementoziv ta shliakhy yikh vyrishennia. Naukovyi visnyk Lvivskoi derzhavnoi akademii veterynarnoi medytsyny. Lviv. 2(4), 86-91 (in Ukrainian).

Melnykova, N.M., Tkachenko, T.A., Lazarenko, I.A. (2010). Kharakterystyka vmistu okremykh mikroelementiv u pechintsi, nyrkakh, selezintsi vahitnykh shchuriv za otruiennia pliumbumom. Biolohiia tvaryn. 12(1), 159-162 (in Ukrainian).

Rozputnii, O. (1997). Vazhki metaly v orhanakh i tkanynakh svynei z promyslovykh kompleksiv. Vet. med. Ukr. 4, 40-41 (in Ukrainian).

Sikora, V.Z., Zakhliebaieva, V.V. (2005). Vplyv solei vazhkykh metaliv na morfolohiiu pechinky. Visnyk Sumskoho DU. 3(75), 5-9 (in Ukrainian).

Cook, J.D., Baynes, R.D., Skikne, B.S. (1992). Iron deficiency and the measurement of iron status. Nutrition Research Reviews. 5, 189-202.

Mazvila, J., Adomaitis, T., Eitminavichius, L. (2001). Heavy metals in Lithuania's soils and plants. J. of Agriculture. 73, 64-90. 